DOI: $10.35681 / 1560-9189.2020 .22 .3 .218803$

УДК 617.751

В. В. Петров, Є. Є. Антонов, В. М. Зенін, А. Ю. Манько, С. М. Шанойло Інститут проблем реєстрації інформації НАН України вул. М. Шпака, 2, 03113 Київ, Україна

\title{
Моделювання та дослідження параметрів концентраторів світАових променів
}

Розроблено метод моделювання мікрорельєфних структур для створення концентраторів світлових потоків із заданими граничними кутами заломлення променів. Розраховано геометричні параметри рельєфу кругового концентратора світлових потоків, який формує у фокусі лінзи рівномірно освітлене коло. Експериментально досліджено виготовлені за результатами моделювання деякі зразки фокусуючих кільиевих пристроїв.

Ключові слова: мікрорельєфна структура, гомогенізачія світлових променів, коефіиієнт пропускання, кутовий розподіл інтенсивностей, моделювання фокусуючої оптики.

\section{Вступ}

Для деяких систем обробки світлових сигналів, які використовуються в оптичних пристроях для автоматичного регулювання вихідного сигналу з чотирьохплощинних фотоприймачів, необхідно перетворювати потік паралельних світлових променів у рівномірно освітлене світлове коло необхідного діаметра, сформоване на певній відстані від лінзи. Для розрахунку геометричних параметрів таких концентруючих лінз можна використати методи, розроблені авторами [1] для моделювання фокусуючих пристроїв з плоскими в перерізі конусними кільцевими робочими гранями. При виготовленні таких пристроїв методом алмазного різання [2] можливо отримати практично дзеркальні робочі поверхні високої оптичної якості, однак розміри таких конусних зон не повинні бути занадто великими для зменшення дискретності зображень, які формуються. При створенні концентраторів світла основна відмінність від методу [1] полягає в тому, що замість формування у фокусі лінзи зображення джерела освітлення, в концентраторах променів необхідно у фокусі сформувати рівномірно освітлене світлове коло. В доступній відкритій літературі відсутні результати розрахунків таких структур, тому виконання подібних досліджень цілком доцільне.

(C) В. В. Петров, Є. Є. Антонов, В. М. Зенін, А. Ю. Манько, С. М. Шанойло 


\section{Метод моделювання параметрів концентраторів потоків світла}

Розглянемо типову схему (рис. 1) фокусуючого мікрорельєфного пристрою [1], яку в подальшому будемо використовувати для розрахунку параметрів світлових концентраторів. За основу візьмемо варіант фокусуючої структури 3 постійним кроком мікрорельєфу $W$, яка $\epsilon$ більш технологічною при практичному виготовленні концентраторів. На рис. 1 зображено модернізовану схему типової структури зі змінними кроком і глибиною рельєфу, де $f$ - фокусна відстань; $n_{0}$ та $n_{1}-$ показники заломлення середовища та матеріалу призмової структури, відповідно; $R_{k}$ - радіуси плоских конусних кільцевих зон $k=1,2, \ldots, N ; \alpha k-$ кути заломлення мікропризм; $\gamma_{k}$ - кут спостереження $k$-зони $з$ центру фокальної площини $F$; $W$ - номінальний крок мікрорельєфу.

Кути падіння променів $\varphi_{1 k}$ дорівнюють кутам заломлення призм $\alpha_{k}$, а кути рефракції $\varphi_{2 k}$ для кожної конусної зони $k$ визначаються за законом Снеліуса [3]. Метою розрахунків є отримання значень кутів $\alpha_{k}$ для всіх плоских граней мікропризм, при яких для кожної зони відбувається фокусування паралельних променів пройденого світла в єдине центральне світлове коло.

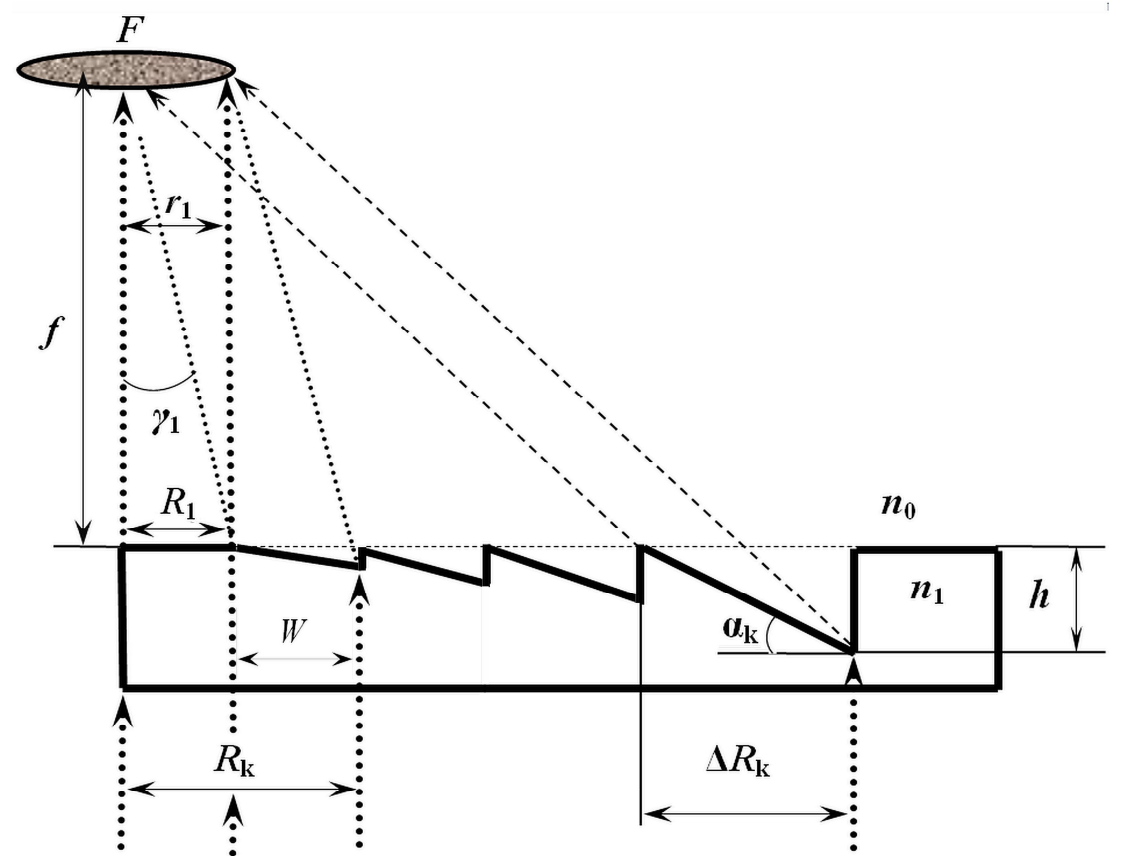

Рис. 1. Схема модернізованого кільцевого конусного фокусуючого елемента Френеля

Особливістю фокусуючих структур, створених методом алмазного різання, $\epsilon$ дискретна зміна заломлюючих кутів мікропризмових зон, внаслідок цього виникає і дискретність сформованих у фокусі зображень, величина дискретності визначається шириною конусних кільцевих фокусуючих зон. Це $є$ принциповою відмінністю від френелівської фокусуючої оптики з асферичними опуклими кільцевими поверхнями [4], коли кути заломлення змінюються безперервно і за допомогою таких структур теоретично можливо сформувати з паралельного пучка світла у фокусі точкове зображення. Високоякісні такі зображення практично не реалі- 
зуються із-за дефектів асферичних поверхонь. Більшість зазначених структур створюється методами фотолітографії або регульованим прямим лазерним записом на фоторезисті. Такі методи дозволяють формувати відомі ступінчаті кіноформні структури [4], в той час як алмазне різання забезпечує практичне виготовлення заломлюючих поверхонь дзеркальної якості з мінімумом оптичних дефектів.

Алгоритм розрахунків фокусуючої структури для реалізації метода алмазного різання передбачає на першому етапі визначення розміру центральної зони 3 радіусом $R_{1}$, яка при виготовленні лінзи залишається плоскою. Розмір цієї зони визначається, перш за все, технологічними вимогами. При виготовленні структури методом алмазного різання [2] швидкість обертання алмазного різця дорівнює нулю в точці $R_{1}=0$, тому значення $R_{1}$ не може бути дуже малим. 3 іншого боку, для формування високоякісних візуальних зображень радіус $R 1$ не може бути і великим - збільшення значення $R 1$ підвищує дискретність зображень, які формуються лінзою. Зазвичай, плоска поверхня в центрі типової фокусуючої структури для формування прецизійних візуальних зображень встановлюється з радіусом $R_{1}=1,0-1,2$ мм. Розмір цієї зони і визначає величину дискретності зображень, які формуються.

Для розглянутої моделі лінзи значення радіусів $R_{k}$ наступних нахилених зон пов'язані з розміром центральної плоскої зони $R$. Розрахункові глибини рельєфу $h$ та ширини зон $W$ поступово збільшуються, що необхідно для концентрації заломлених променів для зон лінзи $\Delta R_{k}$ в центральній зоні $r_{1}$ фокальної площини.

Після визначення радіусу центральної зони $R_{1}$ в точці $R=R R_{1}$ визначається кут $\gamma_{1}$ заломлення променів першою нахиленою зоною $k=1$, 3 якого за законом Снеліуса [3] знаходиться значення кута нахилу $\varphi$ цієї кільцевої зони. При такому куті заломлення промінь 3 точки $R=R 1$ спрямовується в центр зображення в площині фокуса $F$. Кут $\varphi 1$ при розрахунках параметрів лінзи визначає заломлюючий кут $\alpha_{1}=\varphi_{1}$ для всіх променів, що проходять через першу кільцеву призмову структуру:

$$
\begin{gathered}
\gamma_{1}=\operatorname{tg}^{-1}\left(R_{1} / f\right), \\
\varphi_{1}=\operatorname{tg}^{-1}\left\{\sin \gamma_{1} /\left(n_{1} / n_{0}-\cos \gamma_{1}\right)\right\} .
\end{gathered}
$$

Оскільки всі промені, які пройшли через першу конусну зону лінзи шириною $\Delta R_{1}=\left(R_{2}-R_{1}\right)$, заломлюються на цей однаковий кут $\gamma_{1}$, навколо точки $F$ формується світлове коло, діаметр якого становить $\Delta d_{1}=2\left(r_{2}-r_{1}\right)$, де $r_{2}$ та $r_{1}-$ радіуси зон зображення е фокальній площині.

Зазвичай, центральна і перша нахилена зони формуються з однаковою шириною $\Delta R_{k}=R_{1}=W$, що забезпечує фокусування променів в єдине центральне світлове коло (рис. 1). Величина $R_{2}$ другої нахиленої зони для заданого значення $R_{1}$ встановлюється відповідним вибором глибини рельєфу $h: R_{2}=R_{1}+h / \operatorname{tg} \alpha_{1}$.

Після визначення радіусу $R 2$ аналогічно розраховуються параметри рельєфу для нахилених зон рельєфу $k=2,3,4, \ldots, N$, причому на кожному з етапів попередні дані становляться початковими даними комп'ютерних розрахунків для наступного етапу.

Кут $\gamma_{k}$ визначається для кожної із конусних кільцевих зон у точці мінімального iii радіуса. Вважається, що всі промені, які пройшли через кожну з таких ко- 
нусних зон шириною $\Delta R_{k}=\left(R_{k+1}-R_{k}\right)$, заломлюються на цей однаковий кут $\gamma_{k}$ та формують у фокусі відповідне світлове коло, радіус якого визначається значенням $\Delta R k$. При незмінному значенні $r_{1}=R 1$ наступні зони лінзи $k=2,3,4 \ldots, N$ формуються з більшими значеннями $\Delta R_{k+1}=h / \operatorname{tg} \alpha k$, для забезпечення незмінності радіусу зони $r_{1}$ необхідно відповідним чином збільшувати глибину мікрорельєфу $h$.

Запропонований алгоритм [1] дозволяє отримати параметри рельєфу, зокрема радіуси кільцевих зон $R_{k}$ та відповідні кути нахилу граней $\varphi_{k}=\alpha k$ для будь-яких значень $r, f, h$ та для необхідної кількості кроків рельєфу $N$, тобто для необхідного діаметра лінзи $D$.

При створенні концентраторів світла основна відмінність від методу [1] створення фокусуючої френелівської оптики полягає в тому, що замість формування у фокусі лінзи зображення джерела освітлення, в концентраторах необхідно 3 паралельного пучка пройдених світлових променів у фокусі сформувати рівномірно освітлене світлове коло. Розмір цієї центральної зони може бути досить великим. Стримуючим фактором $є$ те, що при формуванні рельєфу методом алмазного різання застосовані алмазні різці мають ріжучу кромку, яка завдовжки не більше 1,6-1,8 мм, тому довжина робочих поверхонь мікропризм $\left(\Delta R_{k} / \cos \alpha_{k}\right)$ або радіуси зон $R_{k}$, перш за все, розмір першої нахиленої зони $R_{2}-R_{1}$, не можуть бути більшими за $\sim 1,5$ мм.

Для усунення цього обмеження необхідно формувати кожну з нахилених зон $k=1,3,4, \ldots, N$ концентратора 3 декількох кільцевих складових мікропризмових елементів, які сформовані з однаковим кутом заломлення мікропризм $\alpha_{k}$. При цьому ширина $\Delta R k$ складових елементів для кожної із зон у сумі дорівнює вибраній ширині центральної зони, що забезпечується відповідним варіюванням глибини рельєфу $h$ і кількості складових елементів $N_{k}$. Фрагмент схеми такого концентратора світловим діаметром $D=52$ мм, що складається з 5 складових мікропризмових зон № 1-5, наведена на рис. 2. Лінза призначена для формування світлового кола діаметром $d=9$ мм на фокусній відстані $f=20$ мм для довжини хвилі випромінювання $\lambda=1,064$ мкм,

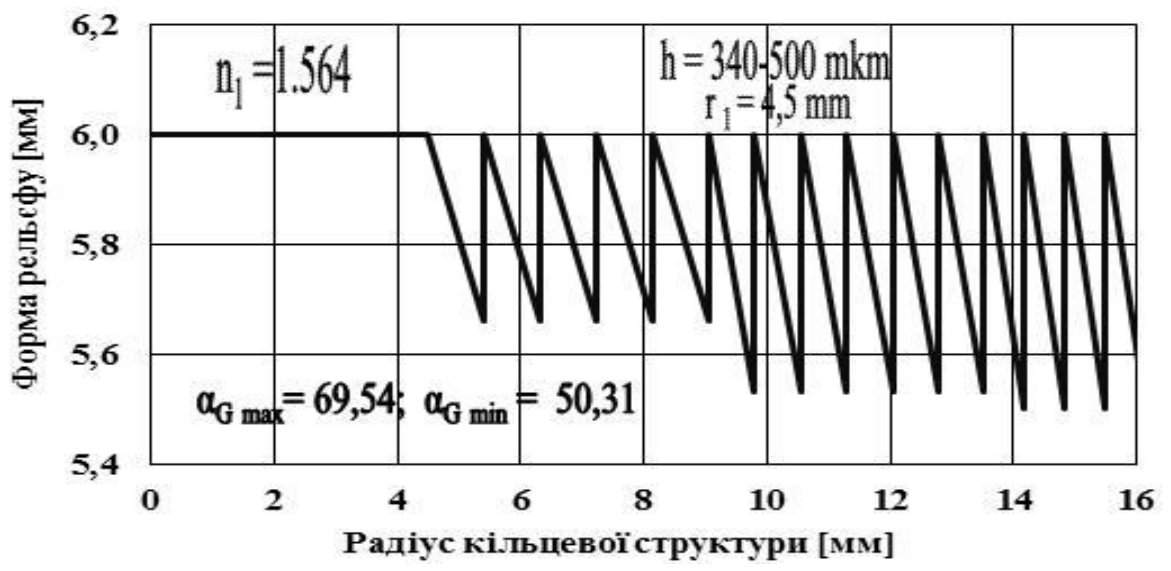

Рис. 2. Переріз кільцевого мікропризмового концентратора світла, створеного зі складових зон 
Результати виконаних розрахунків параметрів зазначеного концентратора, що складається з 5 складових зон № 1-5 загальною кількістю 32 мікропризмові елементи, наведений на рис. 3. Саме такі табличні дані використовувалися при практичному виготовленні модельованого концентратора світлових потоків.

\begin{tabular}{|c|c|c|c|c|c|c|c|c|c|c|c|c|c|c|c|c|c|c|}
\hline \multirow[t]{2}{*}{$\mathbf{n}$} & \multirow{2}{*}{$\begin{array}{l}r_{i}=r_{1}+\Delta r_{i} \\
r_{1}=4.5 \mathrm{~mm}\end{array}$} & \multicolumn{2}{|c|}{$\gamma_{i}=\operatorname{tg}^{-1}\left(r_{i} / f\right)$} & \multirow[t]{2}{*}{$\sin \gamma_{i}$} & \multirow[t]{2}{*}{$\cos \gamma_{\mathrm{i}}$} & \multicolumn{2}{|c|}{$\alpha_{a}=\operatorname{tg}^{-1}\{\sin \gamma /(1,564-\cos \gamma)\}$} & \multirow{2}{*}{$\frac{\Delta r_{i}=h^{*} \operatorname{tg}^{-1} \varphi_{i}}{m m}$} & \multirow[t]{2}{*}{$\beta=90-\alpha$} & \multirow{2}{*}{$\begin{array}{l}\mathrm{h} \\
\mu \mathrm{m}\end{array}$} & \multirow{2}{*}{$\begin{array}{l}\gamma+\alpha \\
\text { deg. }\end{array}$} & \multirow[t]{2}{*}{$\tau(\mathrm{fr})$} & \multirow{2}{*}{$\begin{array}{l}\tau(\mathrm{fr}) \\
\mathrm{x} 100\end{array}$} & \multirow[t]{2}{*}{$\pi\left(\mathrm{r}_{2}^{2}-\mathrm{r}_{1}^{2}\right) \tau$} & \multirow[t]{2}{*}{$\pi\left(\mathbf{r}_{2}^{2}-\mathbf{r}_{1}^{2}\right)$} & \multirow{2}{*}{$\begin{array}{l}\text { Transm. } \\
\text { zone 1-N }\end{array}$} & \multirow[t]{2}{*}{$\pi\left(r_{2}^{2}-r_{1}^{2}\right) \tau$} & \multirow{2}{*}{$\begin{array}{l}\text { Transm. } \\
\text { N-zone }\end{array}$} \\
\hline & & rad & deg & & & rad & deg. & & & & & & & & & & & \\
\hline & & & & & & & & & & & & & & $\mathrm{mm}^{2}$ & $\mathrm{~mm}^{2}$ & $\%$ & & \\
\hline 0 & 0,000 & 0,000 & 0,00 & 0,0000 & 1,0000 & 0,000009 & 0,001 & & & & & & & & & & & \\
\hline 1 & 4,500 & 0,221 & 12,68 & 0,2195 & 0,9756 & 0,357080 & 20,459 & 0,91135 & 69,541 & 340 & 33,14 & 0,949 & 94,900 & 60,3728 & 63,6173 & 94,9 & 60,3728 & 2,86 \\
\hline 2 & 5,411 & 0,221 & 12,68 & 0,2195 & 0,9756 & 0,357080 & 20,459 & 0,91135 & 69,541 & 340 & 33,14 & 0,949 & 94,900 & 26,9299 & 28,3771 & 94,9 & 184,1737 & 8,72 \\
\hline 3 & 6,323 & 0,221 & 12,68 & 0,2195 & 0,9756 & 0,357080 & 20,459 & 0,91135 & 69,541 & 340 & 33,14 & 0,949 & 94,900 & 31,8823 & 33,5957 & & & \\
\hline 4 & 7,234 & 0,221 & 12,68 & 0,2195 & 0,9756 & 0,357080 & 20,459 & 0,91135 & 69,541 & 340 & 33,14 & 0,949 & 94,900 & 36,8347 & 38,8143 & & & \\
\hline 5 & 8,145 & 0,221 & 12,68 & 0,2195 & 0.9756 & 0,357080 & 20,459 & 0,91135 & 69,541 & 340 & 33,14 & 0,949 & 94,900 & 41,7872 & 44,0328 & & & \\
\hline 6 & 9,057 & 0,425 & 24,35 & 0,4125 & 0,9110 & 0,563334 & 32,280 & 0,74406 & 57,720 & 470 & 56,64 & 0,949 & 94,900 & 46,7396 & 49,2514 & & & \\
\hline 7 & 9,801 & 0,425 & 24,36 & 0,4125 & 0,9110 & 0,553334 & 32,280 & 0,74406 & 57,720 & 470 & 56,64 & 0,916 & 91,600 & 40,3772 & 44,0799 & 93,1 & 290,0577 & 13,74 \\
\hline 8 & 10,545 & 0,425 & 24,36 & 0,4125 & 0,9110 & 0,563334 & 32,280 & 0,74406 & 57,720 & 470 & 56,64 & 0,916 & 91,600 & 43,5635 & 47,5584 & & & \\
\hline 9 & 11,289 & 0,425 & 24,35 & 0,4125 & 0,9110 & 0,553334 & 32,280 & 0,74406 & 57,720 & 470 & 56,64 & 0,916 & 91,600 & 46,7498 & 51,0369 & & & \\
\hline 10 & 12,033 & 0,425 & 24,36 & 0,4125 & 0,9110 & 0,563334 & 32,280 & 0,74406 & 57,720 & 470 & 56,64 & 0,916 & 91,600 & 49,9361 & 54,5154 & & & \\
\hline 11 & $12, \pi 7$ & 0,425 & 24,35 & 0,4125 & 0,9110 & 0,553334 & 32,280 & 0,74406 & 57,720 & 470 & 56,64 & 0,916 & 91,600 & 53,1224 & 57,9939 & & & \\
\hline 12 & 13,521 & 0,594 & 34,05 & 0,5601 & 0,8284 & 0,650774 & 37,287 & 0,64353 & 52,713 & 490 & 71,35 & 0,916 & 91,600 & 56,3087 & 61,4724 & & & \\
\hline 13 & 14,165 & 0,594 & 34,05 & 0,5601 & 0,8284 & 0,650774 & 37,287 & 0,64353 & 52,713 & 490 & 71,35 & 0,796 & 79,600 & 44,5540 & 55,9723 & 87,2 & 355,3735 & 16,83 \\
\hline 14 & 14,808 & 0,594 & 34,05 & 0,5601 & 0,8284 & 0,650774 & 37,287 & 0,64353 & 52,713 & 490 & 71,35 & 0,796 & 79,600 & 46,6252 & 58,5743 & & & \\
\hline 15 & 15,452 & 0,594 & 34,05 & 0,5601 & 0,8284 & 0,650774 & 37,287 & 0,64353 & 52,713 & 490 & 71,35 & 0,796 & 79,600 & 48,6964 & 61,1764 & & & \\
\hline 16 & 16,095 & 0,594 & 34,65 & 0,5601 & 0,8284 & 0,650774 & 37,287 & 0,64353 & 52,713 & 490 & 71,35 & 0,796 & 79,600 & 50,7676 & 63,7724 & & & \\
\hline 17 & 16,739 & 0,594 & 34,65 & 0,5601 & 0,8284 & 0,650774 & 37,287 & 0,64353 & 52,713 & 490 & 71,35 & 0,796 & 79,600 & 52,8389 & 66,3805 & & & \\
\hline 18 & 17,382 & 0,594 & 34,05 & 0,5601 & 0,8284 & 0,650774 & 37,287 & 0,64353 & 52,713 & 490 & 71,35 & 0,796 & 79,600 & 54,9101 & 68,9825 & & & \\
\hline 19 & 18,026 & 0,734 & 42,03 & 0,6695 & 0,7428 & 0,683989 & 39,190 & 0,61329 & 50,810 & 490 & 81,22 & 0,796 & 79,600 & 56,9813 & 71,5846 & & & \\
\hline 20 & 18,639 & 0,734 & 42,03 & 0,6695 & 0,7428 & 0,683989 & 39,190 & 0,61329 & 50,810 & 500 & 81,22 & 0,598 & 59,800 & 42,2439 & 70,6420 & 78,7 & 274,6617 & 13,01 \\
\hline 21 & 19,252 & 0,734 & 42,03 & 0,6695 & 0,7428 & 0,683989 & 39,190 & 0,61329 & 50,810 & 500 & 81,22 & 0,598 & 59,800 & 43,6571 & 73,0052 & & & \\
\hline 22 & 19,855 & 0,734 & 42,03 & 0,6695 & 0,7428 & 0,683989 & 39,190 & 0,61329 & 50,810 & 500 & 81,22 & 0,598 & 59,800 & 45,0703 & 75,3685 & & & \\
\hline 23 & 20,479 & 0,734 & 42,03 & 0,6695 & 0,7428 & 0,683989 & 39,190 & 0,61329 & 50,810 & 500 & 81,22 & 0,598 & 59,800 & 46,4835 & 77,7317 & & & \\
\hline 24 & 21,092 & 0,734 & 42,03 & 0,6695 & 0,7428 & 0,683989 & 39,190 & 0,61329 & 50,810 & 500 & 81,22 & 0,598 & 59,800 & 47,8968 & 80,0949 & & & \\
\hline 25 & 21,706 & 0,826 & 47,34 & 0,7354 & 0,6776 & 0,692578 & 39,682 & 0,60264 & 50,318 & 500 & 87,02 & 0,598 & 59,800 & 49,3100 & 82,4581 & & & \\
\hline 26 & 22,308 & 0,826 & 47,34 & 0,7354 & 0,6776 & 0,692578 & 39,682 & 0,60264 & 50,318 & 500 & 87,02 & 0,247 & 24,700 & 20,5823 & 83,3291 & 62,5 & 155,9122 & 7,38 \\
\hline 27 & 22,911 & 0,826 & 47,34 & 0,7354 & 0,6776 & 0,692578 & 39,662 & 0,60264 & 50,318 & 500 & 87,02 & 0,247 & 24,700 & 21,1459 & 85,6110 & & & \\
\hline 28 & 23,513 & 0,826 & 47,34 & 0,7354 & 0,6776 & 0,692578 & 39,682 & 0,60264 & 50,318 & 500 & 87,02 & 0,247 & 24,700 & 21,7095 & 87,8929 & & & \\
\hline 29 & 24,116 & 0,826 & 47,34 & 0,7354 & 0,6776 & 0,692578 & 39,682 & 0,60264 & 50,318 & 500 & 87,02 & 0,247 & 24,700 & 22,2732 & 90,1748 & & & \\
\hline 30 & 24,719 & 0,826 & 47,34 & 0,7354 & 0,6776 & 0,692578 & 39,662 & 0,60264 & 50,318 & 500 & 87,02 & 0,247 & 24,700 & 22,8368 & 92,4567 & & & \\
\hline 31 & 25,321 & 0,826 & 47,34 & 0,7354 & 0,6776 & 0,692578 & 39,682 & 0,60264 & 50,318 & 500 & 87,02 & 0,247 & 24,700 & 23,4004 & 94,7386 & & & \\
\hline 32 & 25,924 & 0,826 & 47,34 & 0,7354 & 0,6776 & 0,692578 & 39,682 & 0,60264 & 50,318 & 500 & 87,02 & 0,247 & 24,700 & 23,9641 & 97,0205 & & & \\
\hline
\end{tabular}

Рис. 3. Фрагмент розрахунків параметрів концентратора

На рис. 2 наведено розрахунковий переріз концентратора 3 досить складними параметрами - необхідно створити світлове коло діаметром $d=9$ мм на відстані $f=20$ мм від плоскої фокусуючої лінзи світловим діаметром $D=52$ мм, тобто відносний отвір лінзи $(f / D)$ складає $\sim 0,38$, що досить екзотично. Моделювання параметрів концентратора виконано для довжини хвилі випромінювання $\lambda=1,064$ мкм, коефіцієнт заломлення полікарбонату $n_{1}=1,564$ використаний 3 роботи [6], товщина утворюючої пластини становить $\delta=6,0$ мм.

Для розглянутого прикладу ширина центрального плоского кола складає, відповідно, $R_{1}=4,5$ мм. Мікропризмові зони № 1-2 також створені аналогічної ширини $\Delta R_{k}=4,5$ мм, для цього зони складено з 5 та 6 окремих мікропризмових елементів і визначено необхідні глибини рельєфу цих зон $h=340$ та 470 мкм, відповідно. Наступні мікропризмові зони № 3-5 також розраховані складовими та створені з 6 та 7 окремих елементів для отримання сумарної ширини кожної із зон $\sim 4,5$ мм. Максимальна глибина рельєфу складає 500 мкм, яка $є$ оптимальною для практичного виготовлення структури. Отримана залежність сумарної ширини кожної із зон 1-5 та окремих елементів $\Delta R_{k+1}$ від радіуса $R_{k}$ наведено на рис. 4 . 
При моделюванні фокусуючої структури залежність коефіцієнта пропускання променів $\tau$ від кута падіння променів $\alpha k$ на внутрішню грань структури розраховано за відомими формулами Френеля [5]. Результати наведено на рис. 5, $a$ : крива 1 - паралельна компонента, крива 2 - перпендикулярна, крива 3 - сумарна залежність.

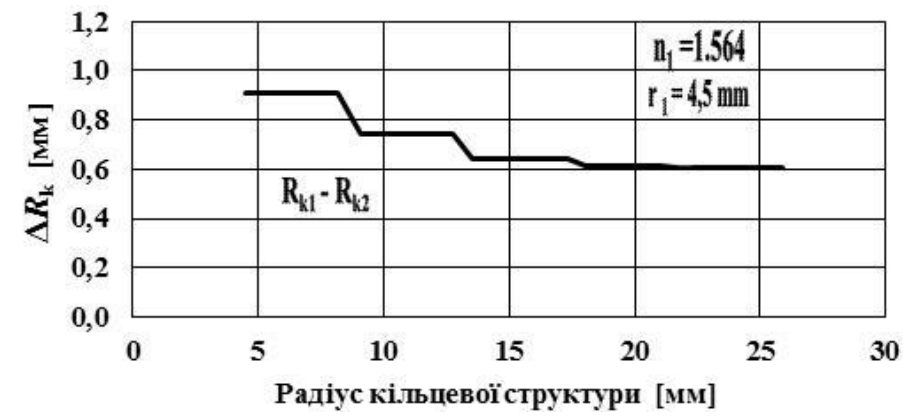

Рис. 4. Ширини складових елементів для різних зон мікропризмового концентратора світла 3 фокусом $f=20$ мм і діаметром $D=52 \mathrm{Mм}$

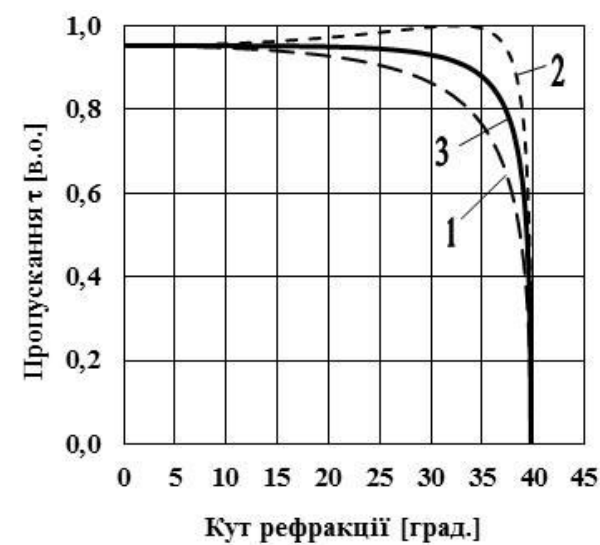

a)

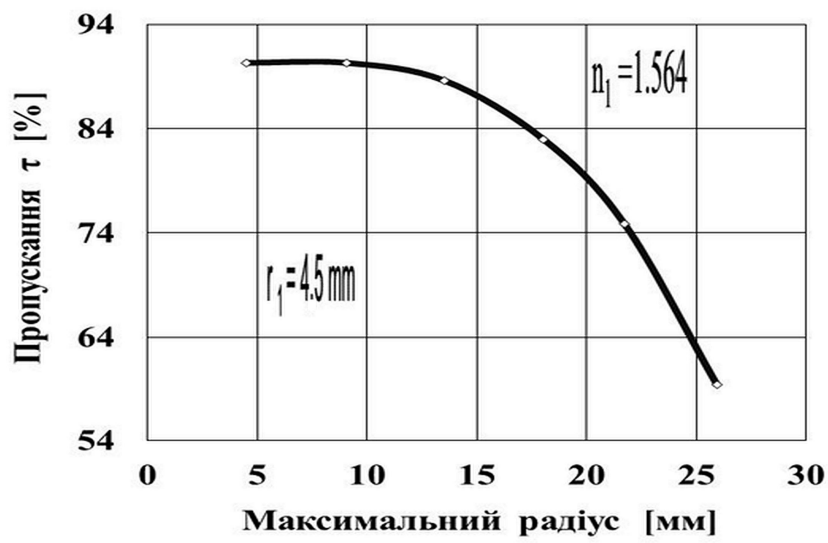

б)

Рис. 5. Коефіцієнт пропускання променів $\tau_{n p}$ : а) теоретична залежність для полікарбонату; б) отримані дані для реального концентратора

Унаслідок збільшення коефіцієнта відбиття променів $\tau_{s}$ при наближенні кутів відбиття до граничного кута $\alpha k$ max значно погіршується загальний коефіцієнт пропускання світла концентратором $\tau_{n p}$, тому збільшення діаметра концентратора $D$ призводить до падіння загального коефіцієнта пропускання $\tau_{n p}$ світла створеною структурою Така залежність наведена на рис. 5,б - центральні зони концентратора пропускають 90,3 \% світла, повнорозмірний концентратор - лише 59,5 \%.

Розрахунки свідчать, що для формування такого концентратора $з$ оптичного полікарбонату $(\Pi K)$ необхідно використовувати алмазний різець 3 кутами ріжучої грані $\alpha_{G}=50,32-69,54$ град. При цьому розрахункові кути нахилу робочих граней мікропризм $\alpha_{k}$ становлять 20,456-39,686 град. Максимальне значення кутів практично збігається 3 граничним кутом променів, який для ПК становить $\alpha_{k \max }=39,746$ град., при такому куті відбувається повне внутрішнє відбиття променів [3]. Тому внесок останньої мікропризмової зони № 5 до загального пройденого світлового потоку становить 7,03 \%, при цьому коефіцієнт пропускання світла через зазначену зону № 5 не перевищує 23,5 \%. 
За цієї причини при подальшому практичному виготовленні концентраторів методом алмазного різання сформовано лише перші нахилені зони з мікропризмами № 1-4, що дозволило підвищити загальний коефіцієнт пропускання структури до значення $\tau_{n p}=74,9 \%$.

Зображення реально створеного за результатами моделювання концентратора світлових променів наведено на рис. 6 . Помітні усі групи № 1-4 призматичних елементів 3 однаковими кутами заломлення, визначеними за табличними даними 3 рис. 3.

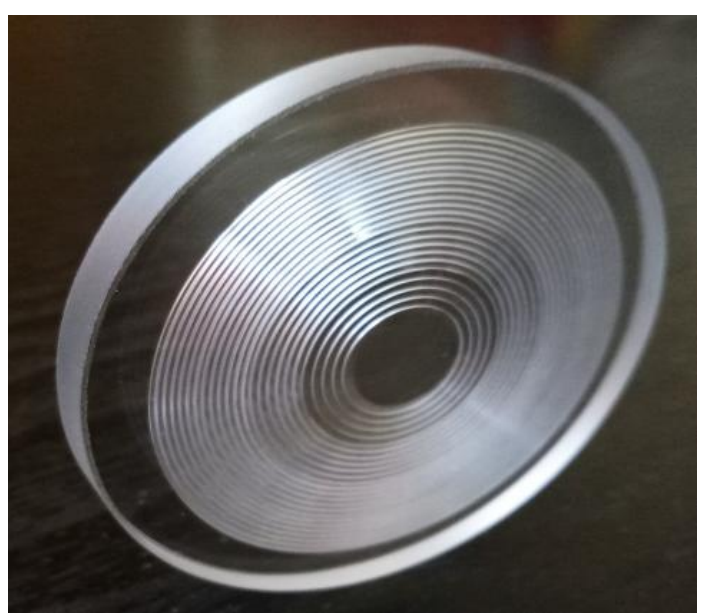

Рис. 6. Загальний вигляд концентратора світла для $n_{1}=1,564$ (ПК для $\lambda=1,064$ мкм), створеного за результатами розрахунків

\section{АосліАження створених}

\section{мікропризмових концентраторів світла}

Для дослідження оптичних параметрів розробленого концентратора було використано програму SolidwoRks 2016 [7], за допомогою якої за наведеними вище табличними даними на першому етапі було створено комп'ютерну модель лінзи (рис. 7).

Модель лінзи у форматі STEP завантажена у програму TracePro 7.3 [8] для здійснення подальшого моделювання ходу променів у наближенні геометричної оптики методом Монте-Карло. Джерело світла являє собою паралельний пучок променів (близько 200 тисяч), які рівномірно розповсюджуються в напрямку, перпендикулярному площині лінзи. Екран являє собою циліндр з радіусом $r_{E}=25$ мм, розташований на певних відстанях $f$ від рельєфної поверхні лінзи. Модельована схема розповсюдження променів через концентратор для різних відстаней спостереження $f=15,20,25$ та 50 мм наведена на рис. 8 - червоним кольором позначені падаючі та заломлені пройдені промені, синім - відбиті та заломлені після відбиття.

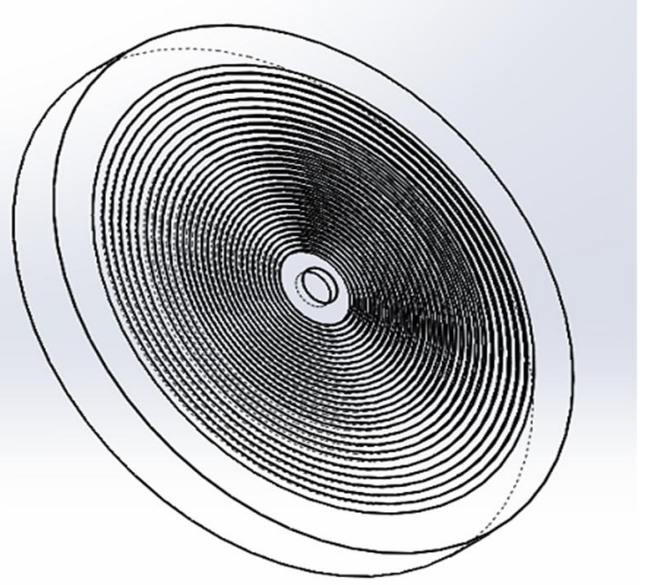

Рис. 7. Модель концентратора, створена за табличними даними розрахунків за допомогою програми Solidworks 2016

На наступному рис. 9 наведено деякі результати з моделювання розподілу інтенсивності на екрані для розглянутого концентратора в заданій точці фокусу $f=20 \mathrm{MM}$. 


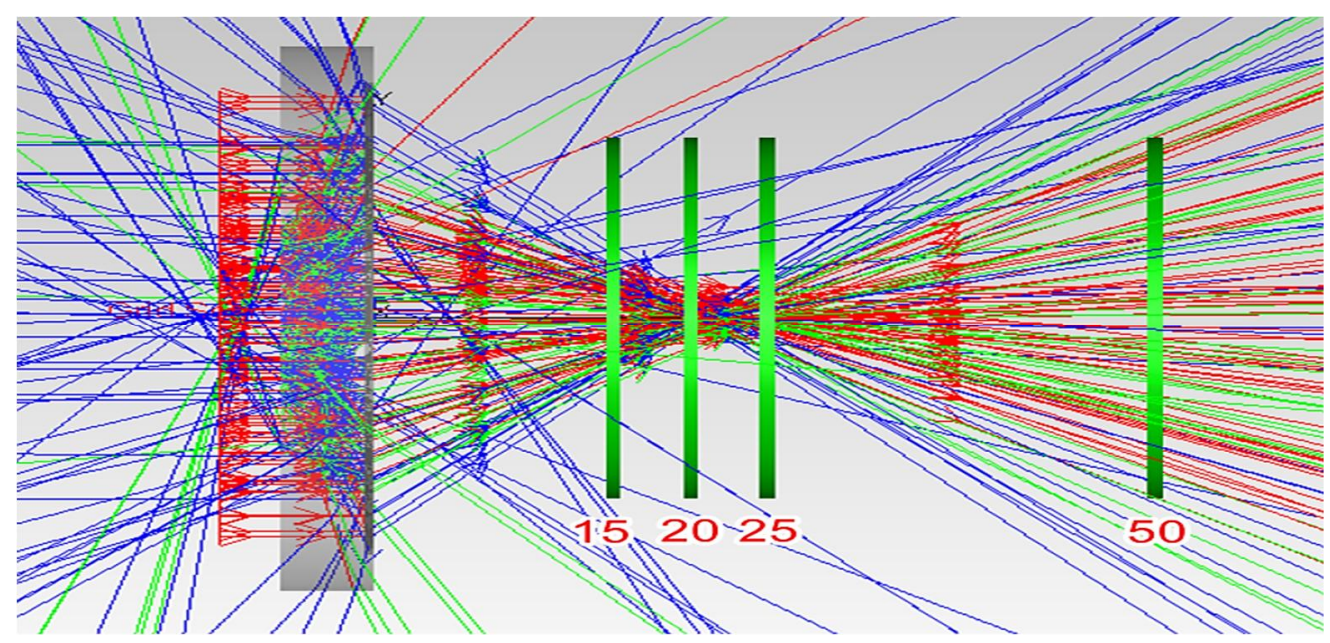

Рис. 8. Схема розповсюдження паралельних променів через концентратор для різних відстаней спостереження: $f=15,20,25$ та 50 мм

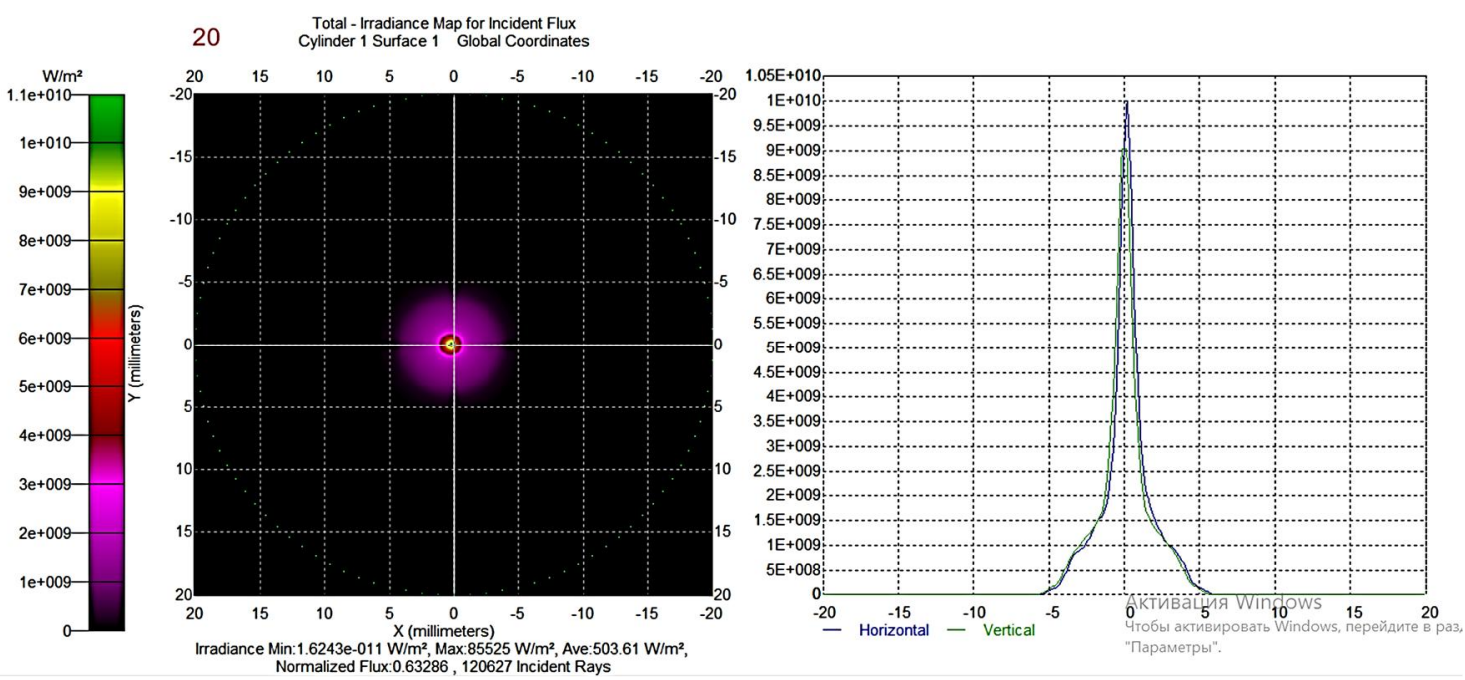

Рис. 9. Зображення на екрані та профіль пучка при трасуванні променів, за умови вибору полікарбонату як матеріалу лінзи для $\lambda=1,064$ мкм та $f=20$ мм

На рис. 10 наведено об'ємний профіль променів при освітленні розрахованої лінзи з полікарбонату світлом інфрачервоного діапазону.

Отримані в результаті моделювання дані свідчать, що розроблений концентратор достатньо ефективно перетворює паралельний пучок променів у світлове коло заданого діаметра, що відповідає поставленій задачі. Розподіл освітленості світла в площині фокусу в периферійній зоні екрана є близьким до однорідного, але спостерігається помітна концентрація світла у вузькій центральній зоні, що пов'язано зі зміною геометрії сфокусованих променів.

При збільшенні відстані спостереження $f$ розроблений концентратор, звичайно, втрачає свої фокусуючі властивості та формує серію кільцевих світлових структур, подібних до наведених на рис. 11 - кожна кільцева призматична зона № 1-4 лінзи, створена з однакових за кутом заломлення елементів, формує у фо- 
кусі світлове коло шириною $\approx 4,5$ мм. Для точки фокусу всі світлові кола збігаються в одне кільцеве зображення, як свідчать дані рис. 9-10.

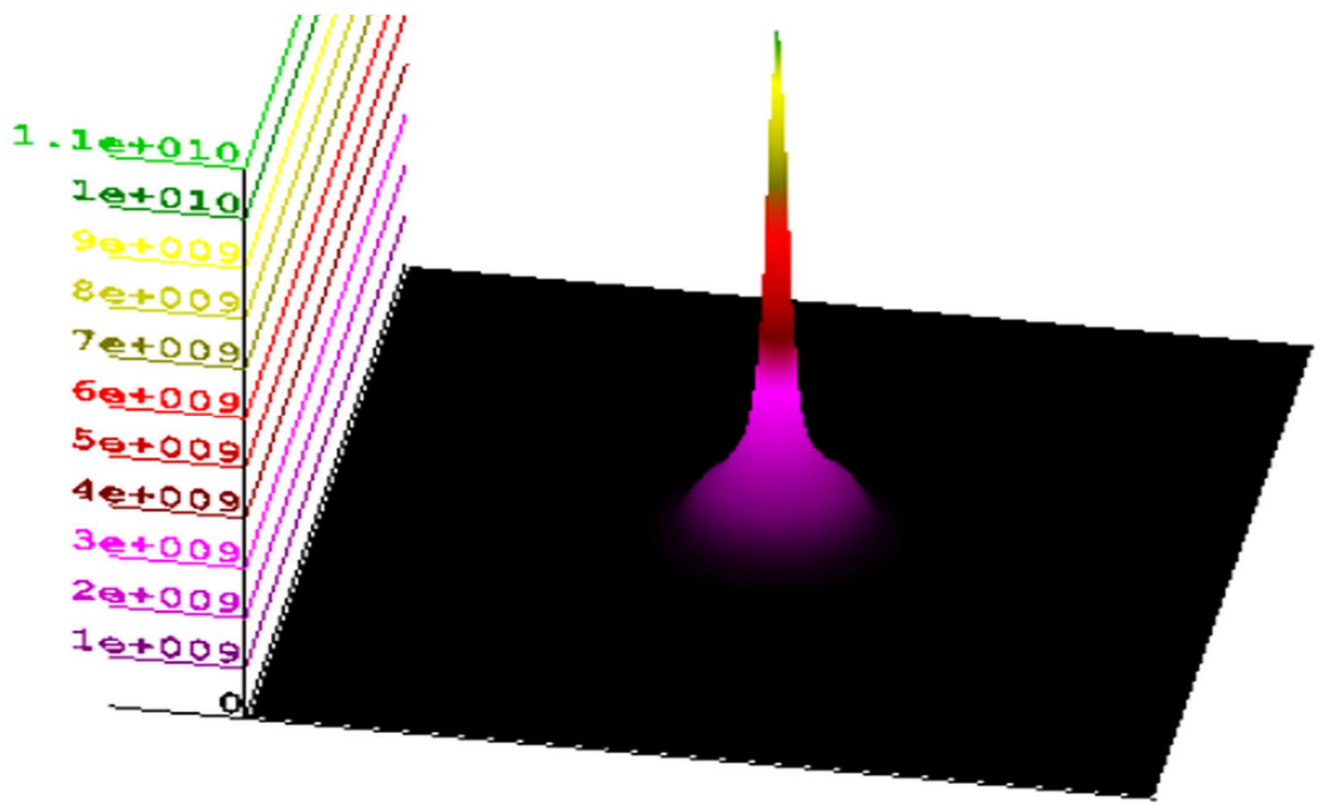

Рис. 10. Модельований об'ємний профіль променів, що пройшли через лінзу з полікарбонату для $\lambda=1,064$ мкм та $f=20$ мм

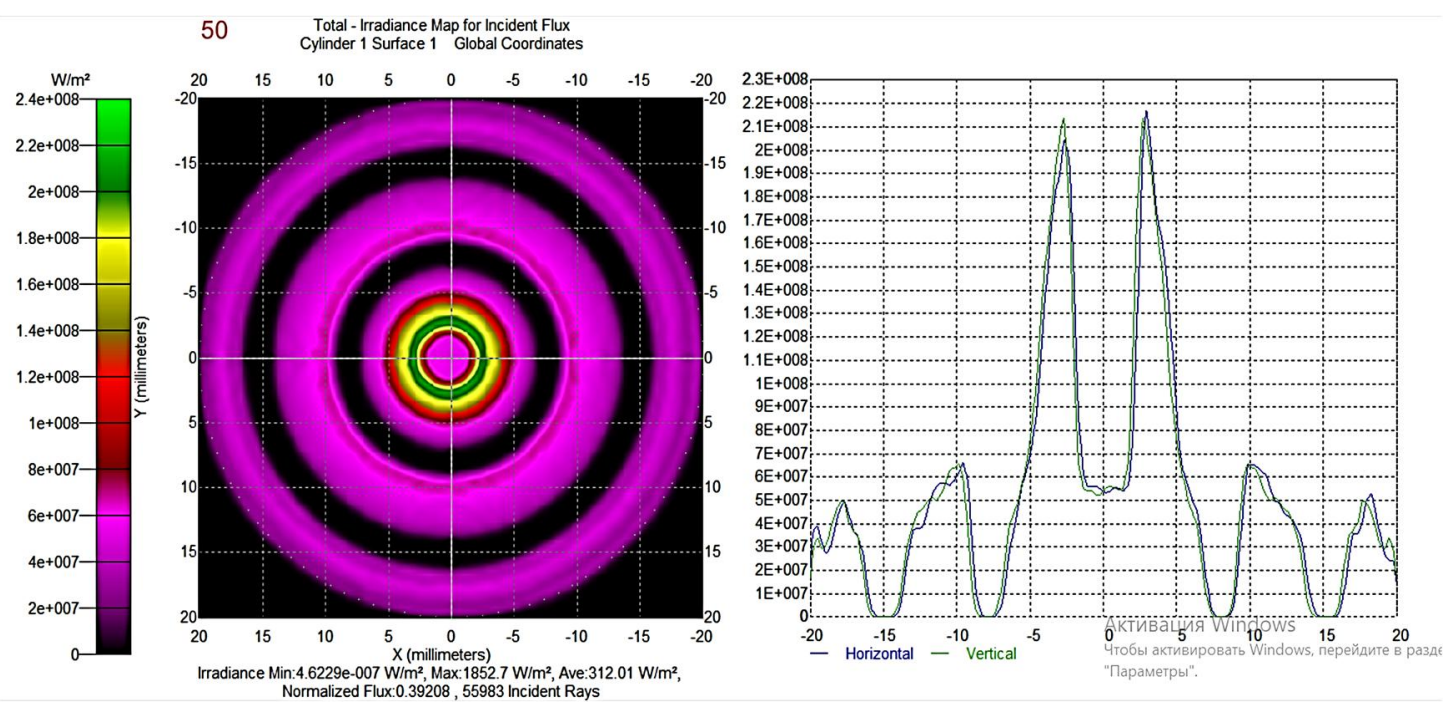

Рис. 11. Зображення на екрані та профіль пучка при трасуванні променів, за умови вибору полікарбонату як матеріалу лінзи для $\lambda=1,064$ мкм та $f=50$ мм

Заміна джерела освітлення 3 паралельними променями на точкове джерело 3 розбіжними променями призводить до відповідних змін фокусуючих властивостей концентратора, який починає функціонувати в нештатному режимі. Схема розповсюдження променів від точкового джерела радіусом $R=5,0$ мм 3 кутом розширення променів 15 град., який розміщено на відстані 100 мм від концентра- 
тора, та зображення на екрані відповідних заломлених променів наведено на рис. $12-13$.

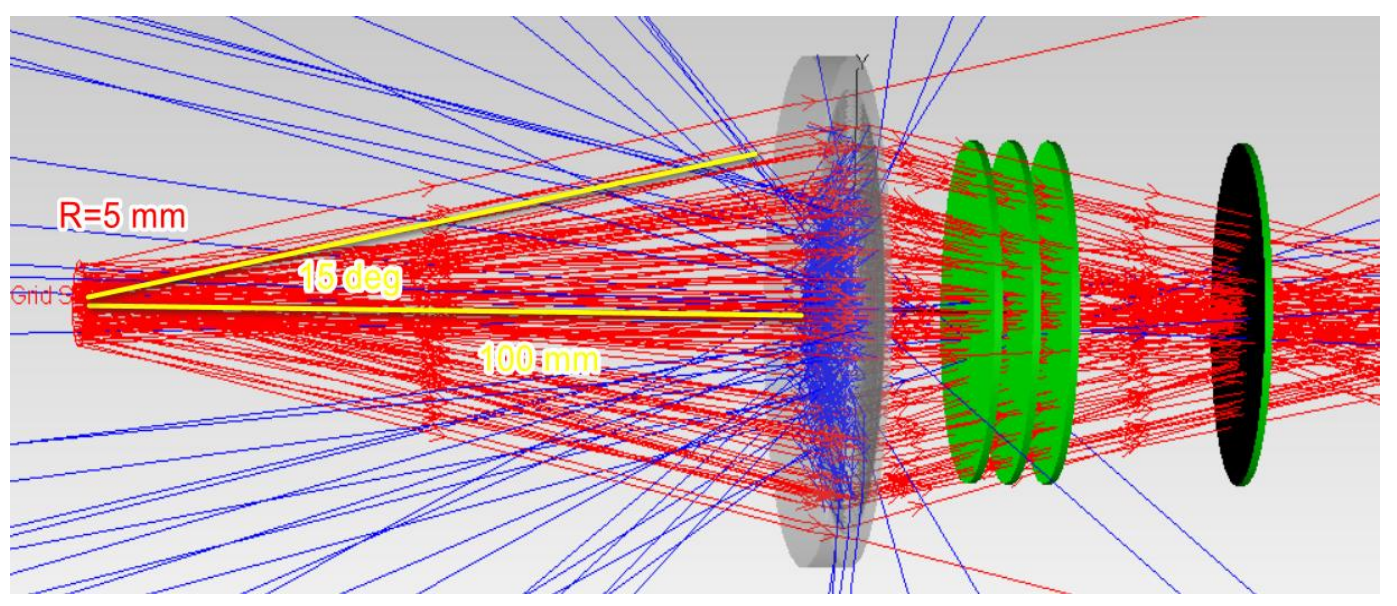

Рис. 12. Схема розповсюдження розбіжних променів через концентратор для різних відстаней спостереження $f=15,20,25$ та 50 мм

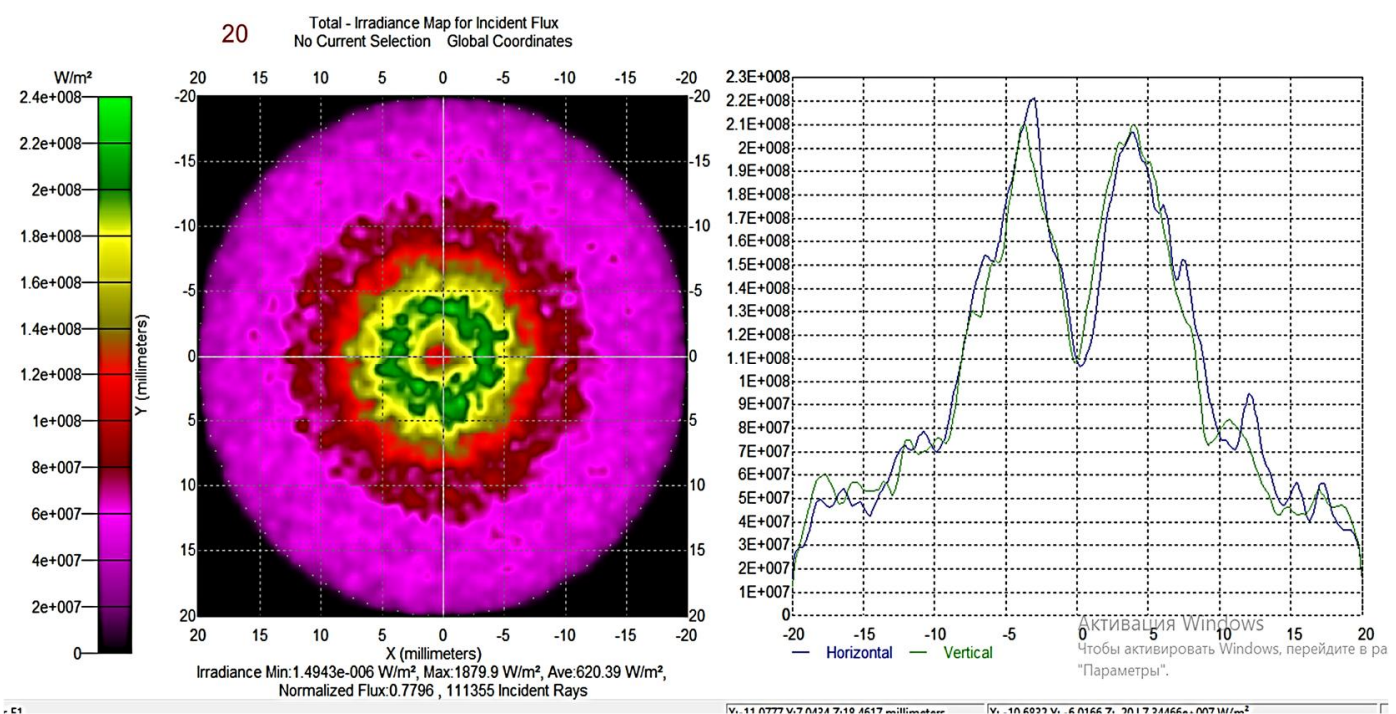

Рис. 13. Зображення на екрані та профіль пучка при трасуванні розбіжних променів для лінзи з полікарбонату для $\lambda=1,064$ мкм та $f=20$ мм

\section{Загальні висновки}

Розроблено алгоритм моделювання параметрів мікропризмових концентраторів світлових потоків. Запропоновано створення фокусуючих структур із груп складових призмових елементів, що забезпечує концентрацію пройденого випромінювання в гомогенізоване світлове зображення в фокусі лінзи. Виконано розрахунки параметрів оптичного концентратора, який забезпечує формування в фокальній площині світлового кола необхідного діаметра.

Результати моделювання підтверджують, що концентратор 3 дискретною зміною кута заломлення, на відміну від асферичних френелівських лінз з плавною 
зміною кутів рефракції, є ефективним лише для заданої розрахункової відстані спостереження, при інших відстанях він втрачає свої фокусуючі властивості. Пропускання світла концентратором, визначене при моделюванні променів, для інфрачервоного діапазону становить $\approx 86,4 \%$, а для видимого - $\approx 84,1 \%$, що свідчить про переважний вклад центральних зон пристрою в сумарне світлопропускання.

1. Петров В.В., Антонов Є.С., Крючин А.А., Шанойло С.М. Микропризмы в офтальмологии. Киев: Наук. думка, 2019. 224 с. ISBN 978-9660-00-1639-2.

2. Бобров В.Ф. Основы теории резания металлов. Москва: Машиностроение, 1979. 344 с.

3. Ландсберг Г.С. Оптика. Москва: Наука, 1976. 928 с.

4. Полещук А.Г. Дифракционные оптические элементы: Методы синтеза и применение: автореф. дис. ... докт. техн. наук. Новосибирск, 2003. 41 с.

5. Петров В.В., Антонов С.Є., Шанойло С.М. Хроматизм світла, дифракція та гострота зору в мікропризмових лінзах Френеля. Реєстрація, зберігання і оброб. даних, 2010. Т. 12. № 1. C.49-54.

6. Sultanova N., KasaRova S., Nikolov I. DispeRsion pRopeRties of optical polymeRs. Acta Physica Polonica A. 2009. Vol. 116. P. 585-587. URL: http://www.RefRactiveindexes.info

7. SOLIDWORKS 2020. Внедрение инноваций в проектировании. URL: http://www.solidwoRks.com.

8. SoftwaRe foR design and analysis of illumination and optical systems. URL: https://www.lambdaRes.com/tRacepRo/ 